Вербицький, 2003 - Вербицький В. В. Еколого-натуралістична освіта в Україні: історія, проблеми, перспективи. - К., СПМ «Аверс», 2003. - 304 с.

Верхратський, 1869 - Верхратський І. Початки до уложення номенклатури и терминологии природописної, народної. - Львів, 1869. - 40 с.

Гісиова, 1991 - Гісцова Л.З. «Щоб защадевши леса... можно было і напредкы чем корыстоватись» // Архіви України. - 1991. - №5 - 6. - С. 75-84.

Екологічне виховання молодших школярів, 2002 - Екологічне виховання молодших школярів: Навч. пос. для студ. пед. ф-тів і вчит. поч. класів / О.А. Біда, Г.П. Волошина, В.П. Гонзуль. - К.:Наук. світ, 2002. $336 \mathrm{c}$.

Енциклопедія освіти, 2008 - Енциклопедія освіти / Акад. пед. наук України. - К.: Юрінком Інтер, 2008. - 1040 c.

Заглада, 1929 - Заглада Н. Побут селянської дитини. Матеріали до етнології. - К., 1929. - 262 с.

\title{
REFERENCES
}

Afonina, 1986 - Afonina V. N Global ecology and problems of the cultural tradition // Interaction of society and nature: Philosophical and methodological aspects of the ecological problem. - Moscow: Nauka, 1986. -P. 303-316.

Begeca, 1995 - Begeka AD Natural sciences folk traditions in ecological education / AD Begeca // Traditions of upbringing in world folk pedagogy: Materials of the International. Scientific Conference, Labor Conference, June 6 - 8, 1995, Rivne. 41 / APNU. - K .; Rivne, 1995. - P. 16-19.

Bromley, 1990 - Bromley Yu., Podolny R. Humanity - These are peoples. - M .: Mysl, 1990. - $391 \mathrm{pp}$.

Bromley, 2008 - Bromley Yu.V. Essays on the theory of ethnos / Yu.V. Bromley: - ed. 2nd, add. - M., 2008. - 437 pp.

Verbitsky, 2003 - Verbitsky V.V. Ecological-naturalistic education in Ukraine: history, problems, perspectives. - K., SPM «Avers», 2003. - 304 p.

Verhratsky, 1869 - Verkharty I. The beginning to the enumeration of the nomenclature and the natural folk. - Lviv, 1869. $-40 \mathrm{p}$.

Gitsova, 1991 - Gitsova L.Z. «To forge the forests ... it was possible and in the future than to be used» // Archives of Ukraine. - 1991. - No. 5-6. - P. 75-84.

Environmental education of junior schoolchildren, 2002 - Environmental education of junior pupils: Teach. pos For the studio Ped .. ft-tev and teaches. beginning of classes / O.A. Bida, G.P. Voloshina, VP Gonzul. - K.: Science. World, 2002. - 336 pp.

Encyclopedia of Education, 2008 - Encyclopedia of Education / Acad. ped Sciences of Ukraine. - K .: Yurincom Inter, 2008. - $1040 \mathrm{pp}$.

Zaglad, 1929 - Zaglad N.B. Peasant child. Materials for ethnology. - K., 1929. - 262 pp.

УДК 37.061. 373.5:37.013(561)

DOI 10.31470/2308-5126-2019-45-2-115-122

Злата Соловей, аспірант IV року навчання ДВНЗ «Переяслав-Хмельнииький державний педагогічний університет імені Григорія Сковороди».
Zlata Solovei, postgraduate student of the IV year of the SHEI «Pereiaslav-Khmelnytskyi Hryhorii Skovoroda State Pedagogical University».

E-mail: zlatasolovei@gmail.com

ORCID 0000-0002-1419-3865

\section{РОЛЬ НЕФОРМАЛЬНОЇ ОСВІТИ У ФОРМУВАННІ ТА РОЗВИТКУ КЛЮЧОВИХ КОМПЕТЕНТНОСТЕЙ ОСОБИСТОСТІ (ДОСВІД ТУРЕЧЧИНИ)}

\footnotetext{
У статті розглядаються проблеми неформальної освіти відповідно до досвіду Туреччини. Дається загальне визначенні поняття неформальної освіти та способи ї̈ впровадження. Висвітлюються основні завдання створення та підтримання неформальної освіти як найбільш демократичної та гуманістичної, ніж інші види освіти, щчо передбачає врахування інтересів особистості та ї̈ потреб, сприяє здобуттю освіти всіма охочими, незалежно від віку, статі, сочіального стану та місця проживання. Аналіз наукових досліджень вчених Туреччини щодо розвитку неформальної освіти країни та ї̈ значення для навчання молоді й дорослих надає нам можливість стверджувати, щьо заходи цьього виду освіти направлені перш за все на
} 
формування (у молоді) та розвитку (у дорослих) ключових компетентностей особистості. При цььому особливої уваги приділяється володінню рідною та іноземною мовами, математичній та екологічній компетентностям, изифровій грамотності та вмінням $і$ здібностям навчатися впродовж життя. Перспективами подальших розробок є аналіз моделей дистанційного навчання для неформальної освіти Туреччини, виокремлення проблем та позитивного досвіду.

Ключові слова: неформальна освіта, позашкільна освіта, навчання впродовж життя, ключові компетентності, дистанційне навчання, освітня реформа, освітня політика, конкурентоспроможність молоді

The article deals with the problems of non-formal education in accordance with the experience of Turkey. The general definition of the concept of non-formal education and its implementation methods are given. There are highlighted the main tasks of creating and supporting of non-formal education as the most democratic and humanistic then other types of education. It involves taking into consideration the interests of the individuals and their needs. As well as it contributes the receiving of education by everyone who has desire, regardless of the age, gender, social status and a place of residence. The analysis of Turkish scientific studies about development of non-formal education in the country and its importance for the education of youth and adults allows us to state that the activities of this type of education are first of all directed to formation (at young people) and development (at adults) of the key competences of the individual. One of the main tasks that has to be set during the implementation of the educational policies of any country is the formation and development of key competencies of the individual (communication by the native language, competence at natural and technical sciences, information and digital competence, life skills, communication by the foreign language, mathematical competence, initiative and entrepreneurship, social and civic competence, awareness and self-expression in the culture sphere, environmental literacy and healthy life) for providing its competitiveness in the global labor market and its lifelong learning. Also, it is significant for improving and maintaining stable economic development, as well as for getting the high qualified workers. At the same time, it is important to introduce not only formal education, that is provided by the "educational programs in accordance with the levels of education, branches of knowledge, specialties (professions) and provides the achievement of the education results of the corresponding level of education and getting the qualifications which are determined by the legislation" but also informal, which has the main goal - to ensure the formation of personality skills and abilities in accordance with its abilities and scientific interests. Taking into consideration all above mentioned, it is interesting to analyze the experience of countries, in particular Turkey, in which special significance is given to the informal education, at the same quantity as to the formal education, for the formation and development of key competencies of the individual. Prospects for further development are the analysis of distance learning models of Turkish non-formal education, identifying problems and positive experiences.

Keywords: non-formal education, extracurricular education, lifelong learning, key competences, distance learning, educational reform, educational policy, youth competitiveness.

Постановка та обгрунтування актуальності проблеми. Одним із основних завдань, що має ставитися при проведенні освітньої політики будь-якої країни, є формування та розвиток ключових компетентностей особистості (спілкування рідною мовою, компетентності у галузях природничих та технічних наук, інформаційно-цифровая компетентність, уміння навчатися впродовж життя, спілкування іноземною мовою, математична компетентність, ініціативність i підприємливість, соціальна та громадянська компетентності, обізнаність та самовираження у сфері культури, екологічна грамотність і здорове життя) для забезпечення іiі конкурентоспроможності на світовому ринку праці та іiі навчання впродовж життя для удосконалення і підтримання стабільного економічного розвитку країни, а також для отримання високваліфікованих кадрів [Концепџія нової української школи, 2016]. При цьому важливим стає впровадження не тільки формальної освіти, що забезпечується «освітніми програмами відповідно до визначених законодавством рівнів освіти, галузей знань, спеціальностей (професій) $\mathrm{i}$ передбачає досягнення здобувачами освіти визначених стандартами освіти результатів навчання відповідного рівня освіти та здобуття кваліфікацій, що визнаються державою», а й неформальної, що має основну мету - забезпечувати формування в особистості вмінь і навичок відповідно до ії здібностей, здатностей та наукових інтересів. 3 цього приводу цікавим $\epsilon$ аналіз досвіду країн, зокрема 
Туреччини, в яких неформальній освіті відводиться особливе значення, на рівні 3 формальною освітою, для формування та розвитку ключових компетентностей особистості.

Аналіз останніх досліджень $\boldsymbol{i}$ публікацій. Проблема створення та підтримання неформальної освіти розглядалася вітчизняними науковцями О. Биковською (проаналізовано Теоретико-методичні основи позашкільної освіти молоді в Україні та Польщі [Биковська, 2006]), Е. Гусейновою, Ю. Лук'яновою (обгрунтовано роль неформальної освіти для безперервної освіти дорослих [Гусейнова, Лук'янова, 2012]), Н. Горук (проаналізовано досвід впровадження неформальної освіти в США [Горук, 2011]), В. Давидовою (проаналізовано досвід використання неформальної освіти дорослих у навчальних гуртках Швеції [Давидова, 2008]), Р. Науменко (проаналізовано державну політику в Україні щодо регулювання розвитку позашкільної освіти як неформальної [Науменко, 2013]), В. Стрижалківської (проаналізовано роль неформальної освіти для підтримки обдарованих дітей у Чехії [Стрижалківська, 2015]) та ін.; дослідниками Туреччини A. Soykana, E. Atasoy (проаналізовано історію та перспективи розвитку неформальної освіти Туреччини [Soykana, Atasoy, 2012]), Hideki Marayuam (досліджено використання неформальної освіти в Туреччині згідно 3 освітніми програмами ООН для сталого розвитку країн [Hideki, 2008]), Meryem Tanriöver (обгрунтовано роль неформальної освіти як складника базової структури національної системи освіти Туреччини [Tanriöver, 2016]) та ін.

Mema cmammi - визначити роль неформальної освіти Туреччини у розвитку ключових компетентності особистості та виокремлення позитивного досвіду для його можливого використання в Україні.

Виклад основного матеріалу дослідження. Сучасна національна освітня система Туреччини, як і України, включає в себе формальну, неформальну та інформальну види освіти. Держави визнають ці види освіти, створюють умови для розвитку суб'єктів освітньої діяльності, що надають відповідні освітні послуги, а також заохочують до здобуття освіти всіх видів. При цьому, неформальна освіта у країнах Європейського Союзу (ЄС) визнається найбільш демократичною та гуманістичною, ніж інші види освіти, оскільки передбачає врахування інтересів особистості та ії потреб, сприяє здобуттю освіти всіма охочими, незалежно від віку, статі, соціального стану та місця проживання [A Memorandum on Lifelong Learning, 2000].

Слід відмітити, що в Туреччині неформальна освіта на державному рівні починає розвиватися на початку 70-их років 20-го століття, коли був затверджений Базовий закон національної освіти № 1739 (англ. Basic Law of National Education). В цьому законі вперше зазначалося, що освіта включає в себе два види - формальну і неформальну.

До прийняття закону № 173, вчені Туреччини Abdullah Soykana, Emin Atasoy [Soykana, Atasoy, 2012] першим важливим кроком щодо підвищення значення неформальної освіти визначають створення у 1955 році Асоціації збереження природи (англ. The Turkish Association for the Conservation of Nature (абревіатура 3 турецької мови TTKD). Члени Асоціації започаткували журнал «Природа і людина», тренінги та семінари 3 проблем екології, неформальне навчання з біології та екології для бажаючих підвищити свій рівень обізнаності $з$ даних сфер науки.

Науковці [Soykana, Atasoy, 2012] також відмічають важливу роль щодо розвитку ключових компетентностей особистості, заснованої в Анкарі у 1989 році, 
Дослідницьку асоціацію сільського середовища та Лісового господарства, в межах якої впроваджувалося неформальне навчання у таких галузях як лісництво, сільське господарство, харчова промисловість, геологія, хімія, машинобудування, соціологія, економічна наука, ландшафтна архітектора, банкірська справа. Основними цілями цієї Асоціації $є$ ідентифікація та вирішення сільських екологічних проблем, починаючи 3 вирубки лісів, дослідження та проведення освітніх заходів 3 метою формування громадської думки в світлі досліджень та запропонованих рішень проблеми через неформальні навчальні гуртки «Дендрологія та школа екології лісу» (англ. Dendrology and school of forest ecology) та «Школа екології грунту» (англ. school of soil ecology). У 2005 році Асоціація провела в Анкарі семінар 3 метою створення основи для природоохоронних заходів, спрямованих на дітей, та підвищення обізнаності у цій темі дорослих.

Серед заходів щодо впровадження неформальної освіти у систему освіти Туреччини слід відмітити заснування в 1992 році відповідно до ініціативи Головного управління молоді та спорту і національної освіти Туреччини (англ. Ministries such as Youth, Sports and National Education), Турецької скаутської федерації (англ. Turkish Scouting Federation). Федерації, що продовжує свою діяльність у рамках Головного управління молоді та спорту і національної освіти Туреччини, у 2006 році була надана автономії. Вона - єдина організація в Туреччині, що є членом Всесвітньої організації скаутського руху (англ. World Organization of Scouting Movement, WOSM) та Всесвітньої асоціації дівчат-скаутів (англ. World Association of Girl Scouts, WAGGGS). Основними завданнями цієї неформальної навчальної організації $€$ популяризація скаутського стилю життя, активної життєвої позиції молоді; залучення дітей і молоді до здорового та активного способу життя; навчання працювати та вирішувати проблеми в групах; розвиток творчих здібностей молоді. Галузі, на які більш за все звертається увага при навчально-виховному процесі у скаутських гуртків: топографія; орієнтування на місцевості (вдень, вночі); в'язання вузлів; ловля риби; плоти та каное; основи першої медичної допомоги; дослідження природи та екології країни; формування екологічної; таборування; поведінка та правила проведення експедиції та ін.

3 огляду на вищезазначене, звернемо увагу, що в межах неформальної освіти у Туреччині, згідно з дослідженнями історії розвитку цього виду освіти турецькими вченими [Soykana, Atasoy, 2012], важливими проблемами вбачаються забезпечення додаткового навчання молоді та дорослих 3 питань екології, лісництва, сільського господарства, харчової промисловості, геології, хімії, машинобудування, соціології, економічної науки, ландшафтної архітектори, при цьому, найбільш уваги приділяється природничо-математечним дисциплінам та технологіям.

Крім цих проблем, Zülfiye Doğa Ortaköylü Uysalli [Zülfiye Doğa Ortaköylü Uysalli, 2017], досліджуючи тему розширення можливостей жінок за допомогою програм неформальної освіти в Туреччині (англ. Empowerment of women through non-formal education programs in Turkey) виокремлює такі завдання неформальної освіти: навчити читати і писати дорослих, які не опанували ці навички; забезпечити цих осіб базовими знаннями $\mathrm{i}$, якщо вони проходили будь-яку офіційну програму освіти, побудувати їх план навчання впродовж життя на базі придбаних знань останнього рівня, якого вони досягли під час навчання.

Ще одним важливим завданням, що здійснюється за допомогою неформальної освіти в Туреччині, є підтримка розвитку професійної освіти (англ. Vocational education). Відповідно до потреб ринку праці Туреччини та світу, 
створюються курси професійної підготовки, зокрема особливої уваги приділяють дистанційному навчанні при університетах Туреччини [Simone Haasler, Eva Anslinger \& Franziska Laudenbach, 2018].

Курси професійної підготовки тривають від двох до чотирьох років, залежно від характеру професії. Теоретична освіта в рамках навчальних програм складає $30 \%$ від загальних занять, решта 70\% припадає на практику професійного навчання. Теоретичне навчання здійснюється в центрах професійно-технічної освіти, професійно-технічних навчальних закладах або освітніх центрах, що пропонуються підприємствами, практичні заняття проводяться на робочих місцях реального виробничого середовища.

Ti, хто закінчують курси професійної підготовки, можуть продовжити навчання для отримання вищої кваліфікації, а ті, хто не навчався на таких курсах, можуть пройти підготовку до вищої майстерності за умови, якщо вони працювали у відповідному секторі протягом п'яти років. Ті, хто має сертифікат про закінчення професійних курсів, можуть працювати за спецальністю 1-3 роки та, після цього періоду, скласти іспит з майстерності.

Слід відмітити, що одним із суттєвих позитивних впливів на розвиток неформальної освіти в Туреччині є створення системи дистанційного навчання [Murphy, 1992]. Так, з 1982 року в країні існує дві основні форми дистанційної освіти - це факультет відкритої освіти (Open Education Faculty, OEF) в університеті Анадолу в Ескішехірі (англ. Anadolu University in Eskisehir) та відкрита середня школа (англ. Open High School, OHS), що діє під керівництвом Міністерства національної освіти.

Факультет відкритої освіти (http://home.anadolu.edu.tr/ udemiray) проводить дистанційне навчання з економіки та ділового адміністрування. Кафедри економіки та бізнес-адміністрування факультету відкритої освіти були реорганізовані в економічний факультет та факультет управління бізнесом у 1993 році.Факультет відкритої освіти постійно розширює свої можливості, що забезпечує доступ до дистанційного навчання громадянам Туреччини, які проживають в інших країнах.

Відкрита середня школа (http://maol.meb.gov.tr) створені для учнів, які не можуть відвідувати формальні навчальні заклади з будь-яких причин, наприклад, перевищення віку для формальної освіти, за станом здоров'я та ін.

У 1995/1996 навчальному році була впроваджена професійно-технічна відкрита освіта (https://www.anadolu.edu.tr/en/academics/vocational-schools) 3 метою забезпечення освітою людей, які здобули початкову освіту, але не отримали професійного навчання з будь-якої причини, а також формування професійних вмінь та навичок тим, хто не мав можливості відвідувати вищі навчальні заклади.

Нижче на рис. 1 відображено роль неформальної освіти у рішенні основних проблем навчання молоді та дорослих, що виокремлено відповідно до проаналізованої наукової літератури. 


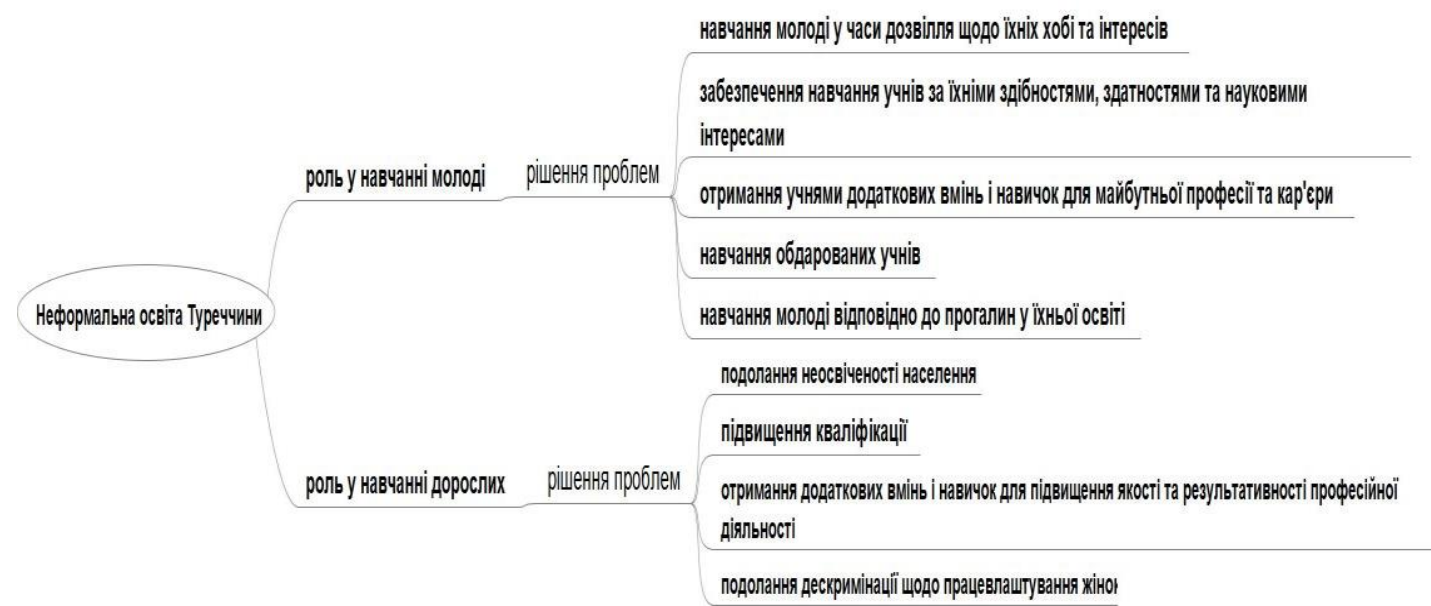

Рис. 1. Схема щодо ролі неформальної освіти у рішенні основних проблем навчання молоді та дорослих, що виокремлено відповідно до проаналізованої наукової літератури Туреччини (авторське бачення)

Згідно з схемою на рис. 1 неформальна освіта Туреччини має особливу роль у навчанні молоді, загалом учнів, що здобувають середню освіту, та у навчанні дорослих, зокрема як навчання впродовж життя.

Неформальна освіта для молоді надає можливість вирішувати такі проблеми: навчання молоді у часи дозвілля щодо їхніх хобі та інтересів; забезпечення навчання учнів за їхніми здібностями, здатностями та науковими інтересами; отримання учнями додаткових вмінь і навичок для майбутньої професії та кар'єри; навчання обдарованих учнів; навчання молоді відповідно до прогалин у їхньої освіті.

Неформальна освіта для дорослих надає можливість вирішувати такі проблеми: подолання неосвіченості населення; підвищення кваліфікації; отримання додаткових вмінь і навичок для підвищення якості та результативності професійної діяльності; подолання дескримінації щодо працевлаштування жінок.

Так, аналіз наукових досліджень вчених Туреччини щодо розвитку неформальної освіти країна та їі значення для навчання молоді й дорослих надає нам можливість стверджувати, що заходи цього виду освіти направлені перш за все на формування (у молоді) та розвитку (у дорослих) ключових компетентностей особистості. При цьому особливої уваги приділяється володінню рідною та іноземною мовами, математичній та екологічній компетентностям, цифровій грамотності та вмінням і здібностям навчатися впродовж життя.

Висновки з дослідження і перспективи подальших розробок. Отже, в Туреччині активно проводяться освітні реформи, основними цілями яких $\epsilon$ підготовка конкурентоспроможної молоді для ринку праці в рідній країні та будьякій країні світу. Впровадження освітньої політики щодо навчання впродовж життя; забезпечення необхідною освітою всього населення Туреччини для підготовки якісних спеціалістів у будь-якій галузі. Міністерство освіти Туреччини прагне розширити мережу центрів та закладів дистанційного навчання 3 метою надання відповідних освітніх послуг для хворих людей та мігрантів.

Неформальна освіта $\epsilon$ необов'язковою та не має організований та систематичний характер, вона може здійснюватися поза межами навчальних освітніх закладів. До сфери неформальної освіти належать індивідуальні заняття під 
керівництвом тренерів чи репетиторів, тренінги та курси, дистанційні курси та ін. Ця освіта не обмежується віком, часовими рамками та не вимагає професійних навиків чи інтелектуальних здібностей учасників. Заклади чи організації, що займаються неформальною освітою, зазвичай, не присуджують кваліфікацій і не провадять формального оцінювання навчальних досягнень учасників. У цьому секторі найчастіше застосовують інноваційні підходи, апробують новаторські методики та технології навчання.

Неформальна освіта забезпечує гнучкий шлях для студентів, які не можуть відвідувати структуроване, повне шкільне навчання формальної початкової та середньої освіти. Неформальне навчання в Туреччині здійснюється за допомогою відкритої освіти, де студенти мають доступ до онлайн матеріалів та курсів, забезпечують можливість двічі на рік скласти іспит із вивчених ними дисциплін для акредитації. Важливу роль також відіграють курси професійної підготовки, що надаються мережею громадських та навчальних центрів, у тому числі шкільними установами під керівництвом Міністерства освіти. Послуги неформальної освіти допомагають студентам продовжувати і закінчувати свою базову освіту, керувати їхньою подальшою освітою, підготовкою кадрів та можливостями для працевлаштування.

Перспективами подальших розробок $є$ аналіз моделей дистанційного навчання для неформальної освіти Туреччини, виокремлення проблем та позитивного досвіду.

\section{ЛІТЕРАТУРА}

Биковська, 2006 - Биковська О.В. Теоретико-методичні основи позашкільної освіти в Україні: автореф. дис. доктора пед. наук. 13.00.01 / Б.О. Володимірва. - Національний педагогічний університет імені М.П. Драгоманова. - К., 2006. - 34 с.

Биковська, 2006 - Биковська О.В. Порівняльний аналіз системи позашкільної освіти України й Польщі / О.В. Биковська / Теоретико-методологічні основи виховання творчої особистості учнів в умовах позашкільних закладів: Матеріали наук.-практ. конф. - К.: Грамота, 2006. - Ч. І. - С. 58-72.

Відомості Верховної Ради, 2017 - Відомості Верховної Ради (2017), Закон України «Про Освіту» № 38-39. [Електронний ресурс]. Режим доступу: http://zakon2.rada.gov.ua/laws/show/2145-19.

Горук, 2011 - Горук Н. М. Проблеми неформальної освіти жінок у США : автореф. дис. ... канд. пед. наук : спец. 13.00.01 / Горук Наталія Михайлівна. - Дрогобич : Дрогобицький державний педагогічний університет ім. І. Франка, 2011. - 20 с.

Гусейнова, Лук'янова, 2012 - Гусейнова Е. І., Лук'янова Ю. М. Неформальна освіта як важливий елемент безперервної освіти //Педагогические науки /4. Стратегические направления реформирования системы образования [Електронний ресурс] http://www.rusnauka.com/11_NPE_2012/Pedagogica/4_106261.doc.htm.

Давидова, 2008 - Давидова В. Д. Неформальна освіта дорослих у навчальних гуртках Швеції : автореф. дис. ... канд. пед. наук : спец. 13.00.01 / Давидова Валентина Дмитрівна. - К. : Київський нац. ун-т ім. Т. Шевченка, 2008. - $20 \mathrm{c}$.

Концепиія нової украӥнської иколи, 2016 - Концепція нової української школи: концептуальні засади реформування середньої школи/ Міністерство освіти і науки України. - 2016, с. 11 [Електронний peсурс]. - - Доступно http://mon.gov.ua/activity/education/zagalna-serednya/ua-sch2016/konczepcziya.html

Науменко, 2013 - Науменко Р.А. Державне регулювання розвитку позашкільної освіти в Україні : автореф. дис ... д-ра наук з державного управління: 25.00.02 / Р.А. Науменко . - Київ, 2013. - 40 с]

Стрижалківська, 2015 - Стрижалківська В.В. Підтримка обдарованих дітей у неформальній освіті Чеської республіки: аналіз діяльності громадських організацій/Освіта та розвиток обдарованої особистості. № 8 (39) $/ 08 / 2015$.

A Memorandum on Lifelong Learning, 2000 - A Memorandum on Lifelong Learning / Commission of the European Communities. - Brussels, 30.10.2000 [Електрон, ресурс]. - Режим доступу: http://arhiv.acs.si/dokumenti/]

Hideki, 2008 - M. Hideki Non-Formal Education for Sustainable Development in Turkey // Editions/AED 70/2008/Poverty And Sustainable Development-https://www.dvv-international.de/adult-education-and- 
development/editions/aed-702008/poverty-and-sustainable-development/non-formal-education-forsustainable-development-in-turkey

Murphy, 1992 - Murphy, K. L. (1992). Sociocultural context of interaction in Turkish distance learning: Implications for distance education teaching. In C. Dillon (Ed.), Proceedings of the First Forum on the Teaching of Distance Education, Norman, OK: University of Oklahoma, pp. 164-184.

Simone Haasler, Eva Anslinger \& Franziska Laudenbach, 2018 - Simone R. Haasler, Eva Anslinger \& Franziska Laudenbach. Comparative perspectives on validation of prior learning - experience from four European countries. HAASLER/ANSLINGER/LAUDENBACH:Issue 10. - 2018) [Електрон, ресурс]. - Режим доступу: www.tvet-online.asia

Soykana, Soykana, 2012 - Atasoy E. Historical Development of Non-Formal Environmental Education in Turkey/ Social and Behavioral Sciences 46 (2012) 736 - 743 [Електрон, ресурс]. - Режим доступу: https://www.sciencedirect.com/science/article/pii/S1877042812013195

Zülfiye Doğa Ortaköylü Uysalli, 2017 - Zülfiye Doğa Ortaköylü Uysalli. Empowerment of women through nonformal education programs in Turkey. A thesis submitted to the graduate school of social sciences of middle East Technical University. 2017, 277 p. [Електрон, ресурс]. - Режим доступу: http://etd.lib.metu.edu.tr/upload/12621277/index.pdf

\section{REFERENCES}

Bykovska, 2006 - Bykovska O.V. Teoretyko-metodychni osnovy pozashkilnoi osvity v Ukraini: avtoref. dys. doktora ped. nauk. 13.00.01 / B.O. Volodymirva. - Natsionalnyi pedahohichnyi universytet imeni M.P. Drahomanova. - K., 2006. - 34 s.

Bykovska, 2006 - Bykovska O.V. Porivnialnyi analiz systemy pozashkilnoi osvity Ukrainy y Polshchi / O.V. Bykovska / Teoretyko-metodolohichni osnovy vykhovannia tvorchoi osobystosti uchniv v umovakh pozashkilnykh zakladiv: Materialy nauk.-prakt. konf. - K.: Hramota, 2006. - Ch. I. - S. 58-72.

Vidomosti Verkhovnoi Rady, 2017 - Vidomosti Verkhovnoi Rady (2017), Zakon Ukrainy «Pro Osvitu» № 38-39. [Elektronnyi resurs]. Rezhym dostupu: http://zakon2.rada.gov.ua/laws/s how/2145-19.

Horuk, 2011 - Horuk N. M. Problemy neformalnoi osvity zhinok u SShA : avtoref. dys. ... kand. ped. nauk : spets. 13.00.01 / Horuk Nataliia Mykhailivna. - Drohobych : Drohobytskyi derzhavnyi pedahohichnyi universytet im. I. Franka, 2011. $-20 \mathrm{~s}$.

Huseinova, Lukianova, 2012 - Huseinova E. I., Lukianova Yu. M. Neformalna osvita yak vazhlyvyi element bezperervnoi osvity //Pedahohycheskye nauky/4. Stratehycheskye napravlenyia reformyrovanyia systemb obrazovanyia [Elektronnyi resurs] http://www.rusnauka.com/11_NPE_2012/Pedagogica/4_106261.doc.htm.

Davydova, 2008 - Davydova V. D. Neformalna osvita doroslykh u navchalnykh hurtkakh Shvetsii : avtoref. dys. ... kand. ped. nauk : spets. 13.00.01 / Davydova Valentyna Dmytrivna. - K. : Kyivskyi nats. un-t im. T. Shevchenka, 2008. - $20 \mathrm{~s}$.

Kontseptsiia novoi ukrainskoi shkoly, 2016 - Kontseptsiia novoi ukrainskoi shkoly: kontseptualni zasady reformuvannia serednoi shkoly/ Ministerstvo osvity i nauky Ukrainy. - 2016, s. 11 [Elektronnyi resurs]. Dostupno: http://mon.gov.ua/activity/education/zagalna-serednya/ua-sch-2016/konczepcziya.html

Naumenko, 2013 - Naumenko R.A. Derzhavne rehuliuvannia rozvytku pozashkilnoi osvity v Ukraini : avtoref. dys ... d-ra nauk z derzhavnoho upravlinnia: 25.00.02 / R. A. Naumenko . - Kyiv, 2013. - $40 \mathrm{~s}$ ]

Stryzhalkivska, 2015 - Stryzhalkivska V.V. Pidtrymka obdarovanykh ditei u neformalnii osviti Cheskoi respubliky: analiz diialnosti hromadskykh orhanizatsii/Osvita ta rozvytok obdarovanoi osobystosti. № 8 (39) /08/2015. 